This PDF is a selection from a published volume from the National Bureau of Economic Research

Volume Title: The Changing Frontier: Rethinking Science and Innovation Policy

Volume Author/Editor: Adam B. Jaffe and Benjamin F. Jones, editors

Volume Publisher: University of Chicago Press

Volume ISBNs: 0-226-28672-X, 978-0-226-28672-3

Volume URL: http://www.nber.org/books/jaff13-1

Conference Date: August 2-3, 2013

Publication Date: July 2015

Chapter Title: State Science Policy Experiments

Chapter Author(s): Maryann Feldman, Lauren Lanahan

Chapter URL: http://www.nber.org/chapters/c13046

Chapter pages in book: (p. 287-317) 


\title{
State Science Policy Experiments
}

\author{
Maryann Feldman and Lauren Lanahan
}

State governments in the United States have experimented with programs that fund science. Many of these programs mimic or complement federal programs, while others attempt to increase industry investment within their borders. Forty-four states in the United States have adopted policy instruments that leverage university resources. Fiscal federalism dictates that different levels of government have specific obligations, with each state responsible for funding its public universities while also influencing private institutions within their borders. The demonstrated and growing interest among state governments in the basic research enterprise suggests that public support for R\&D no longer rests solely at the federal level. State science policy actions over the past thirty years illustrate an evolution toward multilevel funding of US science, with states often motivated to facilitate the commercialization of academic science to capture the returns within their borders. The federal government's role as the source of public support - as outlined by Vannevar Bush's 1945 report Science: The Endless Frontier and discussed by Stephan (chapter 10, this volume), has been adopted by US states, which have great latitude in adopting new initiatives that may be particularly suited to their local circumstances or responsive to specific conditions. In contrast to the sizable literature that examines federal investment in research and development (R\&D) (David, Hall, and Toole 2000; Feller 2007; Payne 2001; Ruegg and Feller 2003; Santoro and Gopalakrishnan 2001), there are few studies that consider state R\&D investments. The magnitude of state

Maryann Feldman is the Heninger Distinguished Professor in the Department of Public Policy at the University of North Carolina at Chapel Hill. Lauren Lanahan is a PhD candidate in the Department of Public Policy at the University of North Carolina at Chapel Hill.

For acknowledgments, sources of research support, and disclosure of the authors' material financial relationships, if any, please see http://www.nber.org/chapters/c13046.ack. 
efforts to leverage science and the reasons behind the adoption of specific state programs are an underappreciated aspect of science policy explored in this chapter.

Individual states within the United States have flexibility to build capacity to either influence firms' R\&D location decisions or leverage federal programs. Since 1980, state government expenditures for university R\&D programs have increased threefold to $\$ 3.13$ billion, and now account for 5.8 percent of all university research in the United States in 2011. ${ }^{1}$ Placing this level of support in context, state and local government investment in academic R\&D is larger than support provided by industry (National Science Board 2012, chapter 8). Moreover, these amounts do not consider state initiatives that fund capital investments in science or programs that support the recruitment of faculty and the promotion of research. To attract firms, states have simultaneously offered R\&D tax credits and attempted to create good business climates (Wilson 2009; Hearn, Lacy, and Warshaw 2014). The adoption of science policy is another means to influence industry location decisions. Moreover, federal funding still accounts for the majority of academic R\&D expenditures. Federal awards are competitive and subject to peer review. States invest in science as a means to increase their share of federal R\&D expenditures (Sapolsky 1971). In addition, with federal funding agencies focused on developing regional centers of innovation often focused on technology-intensive sectors, state science policy is a way to build capacity to participate in cluster initiatives.

Viewing state science policies as experiments may help guide policymakers at the US federal level as well as from other states and countries. The US's federalist multilevel structure was intentionally put in place to create checks and balances on the national government. This structure places state governments in a position to experiment and vet the efficacy of varying programs as they seek to maximize their intended goals (Karch 2007). Scholars and policymakers have an opportunity to evaluate the successes and failures of these state experiments, consider the competitive nature of state actions, and arrive at more enlightened policy recommendations. While federal policy actions are accountable — as mandated by the Government Performance and Results Act of 1993 - the same standard does not hold for state governments. There is less accountability and data are more difficult to access in a uniform format - this particularly pertains to fragmented programs. State-level policy analysis and accountability, nonetheless, is not only critical to constituents, but analysis has the potential to improve policy.

1. Data retrieved from NSF WebCASPAR; NSF Survey of Research and Development Expenditures at Universities and Colleges/Higher Education Research and Development Survey. University R\&D estimates are adjusted for inflation using the Fiscal yr GDP Implicit Price Deflators - base year 2005. State activity is derived from the State/Local Govt Financed Higher Education R\&D Expenditures for S\&E metric. 
Before we can consider the implications of these state science policy experiments, however, it is critical to consider which policies are most appropriate in different circumstances or to even understand what motivates the state adoption of certain policies. To this point there is little guidance except for broad discussions of the economic renewal of states (Fosler 1988; Eisinger 1988; Feller 1997) and some early descriptive studies (Combes and Todd 1996). The creation of a recent typology (Feldman, Lanahan, and Lendel 2014) allows us to examine the factors associated with the adoption of state science programs. Moreover, it allows us to test if states are attempting to promote an enterprise that complements federal efforts and to assess if states promote these programs to catch up or to lead in terms of R\&D activity.

This research is part of a larger research portfolio that first set out to classify state efforts (Feldman, Lanahan, and Lendel 2014); second, to understand motivations relating to state government involvement (the focus of this current chapter); and third, to consider their efficacy and contributions within the national context. This chapter is not an evaluation of these state science programs, but rather considers the circumstances by which states adopt these policies. This is a critical step to consider before examining their efficacy.

The next section provides background on state science policy, with emphasis on state university R\&D programs. This section highlights the trends in the progression of adoption for each of these programs, which includes the Eminent Scholars, University Research Grants, and Centers of Excellence programs. The following sections present the methods and empirical analyses assessing a series of factors associated with the adoption of each of these three programs. The final sections discuss the results for each program, consider the broader state policy portfolio, and conclude with considerations for further research.

\subsection{Background on State Science Policy}

Sapolsky (1971) argues that governors' attention to science and technology resulted from the tripling of federal appropriations in response to Sputnik from 1957 to 1963. The local economic effects of federal expenditures along Route 128 and what was to be later named Silicon Valley were already notable. Many governors sought to replicate that success, with an initial objective of increasing their share of federal science funding. In 1963, New York and North Carolina established entities to parallel the president's science advisor and created state science and engineering foundations modeled after the National Science Foundation (NSF). The US Department of Commerce's State Technical Service Program (STS) and the NSF state science advisor's initiative encouraged active engagement with science policy (Berglund and Coburn 1995). By 1967, twelve governors had science policy advisors (Sapolsky 1968). 
In the 1970s, revenue sharing between the federal and state governments and the devolution of authority from the federal government provided states with the resources and political freedom to experiment with $R \& D$ programs (Vogel and Trost 1979). From 1977 to 1979, forty-nine out of fifty states participated in the NSF State Science, Engineering and Technology (SSET) program, which encouraged states to develop and implement science and technology (S\&T) related strategic plans (Berglund and Coburn 1995). The funding that had been promised for implementation was not subsequently provided. However, the idea that states could strategically leverage science was established (Feller 1990).

During the 1980s academic research was increasingly seen as instrumental in economic growth. The 1980 passage of the Bayh-Dole Act, which granted universities the rights to commercialize results from publicly funded research, coupled with the monetary success of the Cohen-Boyer patents encouraged state legislatures to view universities as engines of economic development (Cozzens and Melkers 1997). Concurrently, the decline of federal and industry support for university R\&D created uncertainty and resulted in a search for alternative sources of revenue (Teich 2009). In response, states began to actively experiment with new programs that involved university science.

State science programs are typically announced with great fanfare and given colorful names. There is a tendency to describe each program as unique and innovative. In reality, however, there are only a few policy levers available to state policymakers. In an effort to build a typology of similar programs, Feldman, Lanahan, and Lendel (2014) identify commonalities across state science initiatives. ${ }^{2}$ Through this effort, three consistent state initiatives aimed to promote innovation capacity through university research institutions were identified: Eminent Scholars, University Research Grants, and Centers of Excellence programs. Table 9.1 provides the year that each state initially adopted each of the three programs, illustrating the variation in the order of adoption and in the combination of programs adopted.

The Eminent Scholars program provides funding for a chaired position to attract world-class senior researchers to public and private universities located within the state boundaries. This program can be conceptualized as an investment in human capital through the attraction of what Zucker and Darby (1996) term "star scientists." This program demands substantial upfront costs, often ranging between \$3-6 million per scholar to support the scholar's salary, lab materials, graduate students, administrative support, and overhead. Despite these notable costs, this program is centrally premised on the idea that these scholars will recover the state's investment by the following: (a) building research capacity within the university, (b) leveraging addi-

2. Data collection efforts to identify the portfolio of state $R \& D$ university programs includes the following: (a) state-funded, (b) codified in a policy document, (c) focus on university R\&D, and (d) administered by a state agency (Feldman, Lanahan, and Lendel 2014). 
Table 9.1 Year of state science policy adoption

\begin{tabular}{|c|c|c|c|}
\hline & Eminent Scholars & University Research Grants & Centers of Excellence \\
\hline Alabama & & 1983 & 1975 \\
\hline \multicolumn{4}{|l|}{ Alaska } \\
\hline Arizona & 1991 & 2006 & \\
\hline Arkansas & 2002 & 1983 & 1990 \\
\hline California & & 2005 & \\
\hline Colorado & & & 1983 \\
\hline Connecticut & 2006 & 1993 & 1965 \\
\hline Delaware & & 1984 & 1994 \\
\hline Florida & 2006 & & 1982 \\
\hline Georgia & 1990 & 1990 & 1990 \\
\hline \multicolumn{4}{|l|}{ Hawaii } \\
\hline Idaho & & & 2003 \\
\hline Illinois & & & 2003 \\
\hline Indiana & & 1999 & 1983 \\
\hline \multicolumn{4}{|l|}{ Iowa } \\
\hline Kansas & 2004 & 2000 & 1983 \\
\hline Kentucky & 1997 & 1997 & 2003 \\
\hline Louisiana & 1987 & 1987 & \\
\hline Maine & & 1990 & 1988 \\
\hline Maryland & & & 1985 \\
\hline Massachusetts & & 2004 & 2009 \\
\hline Michigan & & 1999 & 1981 \\
\hline Minnesota & & & 2005 \\
\hline Mississippi & & & 1999 \\
\hline Missouri & 1995 & & 1986 \\
\hline Montana & & 1999 & 1988 \\
\hline Nebraska & & 1988 & 1987 \\
\hline \multicolumn{4}{|l|}{ Nevada } \\
\hline New Hampshire & & 1991 & 1991 \\
\hline New Jersey & & 2007 & 1984 \\
\hline New Mexico & & & 1983 \\
\hline New York & 1999 & 2000 & 1983 \\
\hline North Carolina & 1986 & 1984 & 1980 \\
\hline North Dakota & & & 2006 \\
\hline Ohio & 1983 & 1998 & 1984 \\
\hline Oklahoma & 2006 & 1985 & 1989 \\
\hline \multicolumn{4}{|l|}{ Oregon } \\
\hline Pennsylvania & 2006 & & 1988 \\
\hline Rhode Island & & & 1996 \\
\hline South Carolina & 1997 & 1983 & 1983 \\
\hline South Dakota & & 1987 & 2004 \\
\hline Tennessee & 1984 & & 1984 \\
\hline Texas & 2005 & 1987 & \\
\hline Utah & & 2006 & 1986 \\
\hline \multicolumn{4}{|l|}{ Vermont } \\
\hline Virginia & 1964 & & 1986 \\
\hline Washington & 2007 & 2005 & \\
\hline West Virginia & & 2004 & \\
\hline Wisconsin & 1998 & 2007 & \\
\hline Wyoming & 2005 & & 2008 \\
\hline
\end{tabular}

Source: Feldman, Lanahan, and Lendel (2014). 
tional federal and private funds, (c) serving as research magnets for industrial recruitment, and (d) ultimately generating revenue from commercialized research (Bozeman 2000; Feller 1997). By providing funds for endowed chairs at research-university campuses, states seek to increase innovative activity by cultivating a rich knowledge economy rooted by these individuals.

Virginia was the first to adopt this program in the 1960s; however, other states did not begin to introduce the program until the 1980s. With Ohio serving as the second adopter in 1983, only five additional states implemented the program within the following decade - these include Tennessee, North Carolina, Louisiana, Georgia, and Arizona. During the latter part of the 1990s, only a handful of states selected to adopt the program. However, this program gained the greatest traction after 2001 with nine states introducing it within a six-year period between 2002 and 2007. Arguably, this recent surge may have resulted from state reports published in the late 1990s highlighting the notable benefits of the state programs. As of 2009, twenty-one states were identified as having an Eminent Scholars program. State and local officials interviewed were very enthusiastic about the potential of the program to build academic resources (Feldman, Lanahan, and Lendel 2014).

The Georgia Research Alliance (GRA) and Kentucky's "Bucks for Brains" stand out as exemplary Eminent Scholars programs (Bozeman 2000; Youtie, Bozeman, and Shapiro 1999). One illustrative example of the program's benefits lies with a distinguished IBM researcher who was recruited to the GRA program for $\$ 1.055$ million and in return secured an NSF grant to establish an Engineering Research Center in Electronic Packaging worth a total value of $\$ 40$ million over a three-year period (Combes and Todd 1996). Kentucky's "Bucks for Brains" initiative increased the number of endowed chairs and professorships in the state by over fivefold from 1997 to 2010, while extramural research expenditures from two of Kentucky's research universities - the University of Kentucky and the University of Louisville - increased by roughly 250 percent over the same time period. ${ }^{3}$

The second state university-based program, the University Research Grants, provides state grants to support university science and engineering (S\&E) research. Feldman, Lanahan, and Lendel's (2014) defining criteria for the University Research Grants programs are the following: (a) grants oriented toward basic scientific research, (b) grants available to all researchers at universities or research institutions within the state, (c) grants that do not fund physical infrastructure, and (d) grants that do not require supplemental funding by an industrial partner. ${ }^{4}$ As of 2009 , twenty-nine states were identified as having a University Research Grants program.

3. Source: http://cpe.ky.gov/news/mediaroom/releases/nr_110811.htm.

4. We consider research grants that require matching funds from firms as a separate category that creates collaboration and leverages university resources. See the later discussion of Centers of Excellence. 
The first state to adopt a University Research Grants program was Arkansas in 1983. Named the Basic Research Grant Program, the primary aim of the program was to build "the state's scientific infrastructure and improve the ability of Arkansas research scientists to compete for awards at the national level by awarding grants to researchers at the state's colleges and universities." ${ }^{5}$ This program targeted individual researchers who had not previously received federal funding and required a 40 percent cash or inkind contribution match by the individual's home institution. The primary intention of this program, as stated in the research objectives, was "to use state funds as an incentive to get scientists interested in new areas of research and to provide them with a track record that will help them to compete for federal monies, thereby bringing more research funds to the state" (Berglund and Coburn 1995, 84). The idea of improving the ability of scientists to compete for federal funds is consistent for these programs, suggesting that states perceive themselves to be lagging in federal R\&D funding.

The Center of Excellence - the third state university-based program - is geared for later-stage university research activity by focusing on university and industry collaboration. This program aims to build capacity by investing in physical infrastructure and strengthening research partnerships with industry. Connecticut adopted this program in 1965, followed by Alabama in 1975. As of 2009, thirty-seven states were identified as having a Centers of Excellence program. These programs include state initiatives alternatively called University Research Centers, Advanced Technology Centers, and Centers of Advanced Technology. The important differentiating criterion of this program lies with the more central, active role of the university's industrial partners. Given the breadth of organizational forms and research foci across Centers of Excellence programs, both in terms of research scale and scope, scholars have struggled to reach a consensus on the definitive features that characterize these unique research organizations (Aboelela et al. 2007; Mallon and Bunton 2005; Youtie, Libaers, and Bozeman 2006; Friedman and Friedman 1982).

Feldman, Lanahan, and Lendel's (2014) review identified four common features of Centers of Excellence programs. These include: (a) a directed research mission focused on basic and applied research, (b) emphasis on graduate training, (c) collaboration between universities and industry, and (d) a strong research orientation directed toward a specific industry sector or technology. Despite these common features, some states place greater emphasis on the partnership with industry, while others are more concerned with the research program. The Massachusetts' Centers of Excellence (2004) serves as an exemplar of the latter, placing a concerted aim on improving emerging technologies such as biotech and nanotech. The Florida Technology Development Initiative, however, exemplifies the former. This Cen- 
Table 9.2

Trends of initial policy adoption of Centers of Excellence, University

Research Grants, and Eminent Scholars programs

\begin{tabular}{|c|c|c|c|c|}
\hline \multirow[b]{2}{*}{ Policy } & \multirow[b]{2}{*}{ Number of states } & \multicolumn{3}{|c|}{ Year adopt first program (state) } \\
\hline & & Mean & First to adopt & Most recent to adopt \\
\hline $\begin{array}{l}\text { Centers of } \\
\text { Excellence }\end{array}$ & 28 & 1987 & 1965 (CT) & 2006 (ND) \\
\hline $\begin{array}{l}\text { University } \\
\text { Research Grants }\end{array}$ & 14 & 1992 & $1983(\mathrm{AR}, \mathrm{SC})$ & 2005 (CA, WA $)$ \\
\hline Eminent Scholars & 9 & 1988 & 1964 (VA) & 2005 (WY) \\
\hline
\end{tabular}

ters of Excellence program promotes both functions of promoting research excellence and facilitating collaboration with industry for conduit building.

Among the portfolio of the three university programs the Centers of Excellence is not only the most widely diffuse; states tend to adopt it first. This suggests a prioritization of making investments in academic research directly linked to industrial activity over supporting more upstream efforts that are characteristic of the Eminent Scholars and University Research Grants programs. The descriptive statistics presented in table 9.2 show that twenty-eight states adopt the Centers of Excellence first, with Connecticut adopting first in 1965. Fourteen states initially adopted the University Research Grants, and nine initially adopted the Eminent Scholars program. These trends of adoption demonstrate a slightly different progression of state policy actions than presented by Plosila (2004). He groups the evolution of state S\&E policy activity linked to economic development programs and practices into three stages - 1960s to 1970s, 1980s, and 1990s — with the first focused on bolstering S\&T programs, the second marking a shift toward university-based economic development initiatives, and the third directed to technology alliances and trade associations linking S\&T to economic growth. Feldman, Lanahan, and Lendel's (2014) review of the portfolio of state university-based programs, however, finds little state university-based activity prior to the 1980s, with the pace of adoption remaining strong in the most recent decade after the turn of the century. Moreover, over the past thirty years states have adopted a range of programs from more upstream programs aimed to bolster the basic research enterprise within the university (Eminent Scholars and University Research Grants) to more downstream initiatives that link university research with industry (Centers of Excellence).

This descriptive analysis suggests that state science policy adoption is not random, but rather maps out in a systematic manner. Currently, our understanding of state science policy tends to rely on case studies that examine single programs and tends to provide more operational details rather than considering the motivation to adopt programs. While there is little theory to directly guide choices for state science programs, there are two broad 
literatures that we can draw from, specifically the state policy diffusion literature and literature on science policy. This analysis draws from these two distinct, yet complementary literatures to identify a series of factors that likely motivate state university R\&D policy adoption.

\subsubsection{What Motivates State Science Policy?}

Since 1985, state governors have been convening annually at the National Governors Association (NGA). Each year, the chair presents a policy-based initiative, directing state attention to a range of issues from education, to healthcare, to economic development and R\&D. Four initiatives have focused on the latter set-1988-89 NGA Chair Gov. Gerald Baliles's Initiative, America in Transition: The International Frontier; 1999-2000 NGA Chair Gov. Michael Leavitt's Initiative, Strengthening the American States in a New Global Economy; 2006-07 NGA Chair Gov. Janet Napolitano's Initiative, Innovation America; and 2011-12 NGA Chair Gov. Dave Heineman's Initiative, Growing State Economies. These national initiatives highlight that states need to invest in science for future economic growth. State policymakers operate with limited resources subject to bounded rationality in their policy decisions (Simon 1978). Given these limitations, they tend to rely on cues from other sources in their decision making. Directed attention on these issues at the annual governors meeting not only raises awareness to the initiative, but also may prompt governors to act within their own jurisdictions.

Moreover, these NGA initiatives point toward a broader economic restructuring that began in the 1980s, motivating many states to adopt science policy programs. Democratic governors pursued technology-based economic development as part of a new strategy. Widely known as "Atari Democrats" these democratic governors sought a contemporary equivalent of the New Deal that would revitalize the economy (Wayne 1982). Named after a thenpopular consumer electronic game, the ideology favored R\&D investment in growing industries and academic research figured prominently in their plans. Therefore, we expect that states are more likely to adopt one of the state science university policies when a democratic governor is in office. Additionally, there is considerable research to show that elected officials hold greater clout at the beginning of their term; thus we expect the state policy activity to take place during the first two years the governor is elected into office (Berry and Berry 1990).

The idea that states benchmark against one another is well established. Many times states that are lagging in terms of $R \& D$ expenditures or high tech capacity will be motivated to adopt science policy initiatives in order to catch up with their peers. Taylor's (2012) recent paper on the role of governors as economic problem solvers argues that a lagging economy or a low level of R\&D may provide an incentive to implement S\&T initiatives. While the precise referent group may be difficult to define, the literature has 
considered diffusion among contiguous states. These data do not support that pattern, but the prominence of the NGA suggests that benchmarking may be national. States that are behind the national average may be more likely to adopt science policies.

The ability to make these investments, however, will likely be related to the state's fiscal condition. In their influential study on state policy diffusion, Berry and Berry (1990) found that the fiscal health of the state budget influenced state lottery adoptions. While lotteries augment state budgets, S\&T programs require slack resources and ability to fund programs that may be considered longer-term investments and discretionary. As such, we anticipate that states would be more likely to have science policy programs in years when they have fiscal growth.

In addition, certain states have demonstrated a commitment to science through previous efforts, suggesting that some states may have a proclivity toward supporting these types of science-based initiatives. In Sapolsky's (1968) review of science policy for state and local governments, he identified twelve states that had taken early action to establish science advisory units. These positions were created shortly after the federal science advisory position was established and reflect an early commitment by the states for science policy that has likely carried through our time frame of interest.

National trends of federal and industry R\&D activity likely drives state actions. Historically, federal and industry R\&D investments have been primary sources of support for S\&T activity, overshadowing investment from state governments and other sources of funding. The federal government tends to lead in supporting more upstream activity, while industry is more prominent in supporting more downstream efforts. Moreover, research within the policy diffusion literature finds states rely on the federal government when making policy decisions. As an illustrative example, Baumgartner, Gray, and Lowery (2009) consider the nature of vertical policy diffusion between congressional activity and state lobbying actions and found the top-down influence to be considerable. The results suggest that federal $\mathrm{R} \& \mathrm{D}$ actions guide subsequent state policy activity. In this case, we expect that increased federal $R \& D$ spending will prompt greater state attention to science policy initiatives. This expectation is reinforced by a series of studies (Blume-Kohout, Kumar, and Sood 2009; David, Hall, and Toole 2000; Diamond 1999; Payne 2001) providing evidence that additional private support results from federal investment in $\mathrm{R} \& \mathrm{D}$ results. This literature finds evidence of a complementary or crowding-in effect between these two sources. Although these studies focus on the relationship between federal funding and private $\mathrm{R} \& \mathrm{D}$, a complementary relationship likely holds for state governments as well as for the adoption of state policies designed to contribute to the R\&D enterprise. Increased federal investment in science is likely to motivate state attention to science policy. We anticipate that state policy actions will complement federal and industry science investments. 
Our understanding of state R\&D activity is relatively nascent compared to federal R\&D policy actions, thus the quantitative analyses in the next section serves as an exploratory effort toward understanding whether and how economic, political, and R\&D-related factors influence state science policy-making decisions. We estimate the impact of the economic, political, and R\&D-related factors associated with states adopting one of the three university state science programs, respectively.

\subsection{Methods}

We employ a Cox proportional hazard model (equation [1]), based on semiparametric assumptions about the distribution of adoptions. ${ }^{6}$ In contrast to parametric models, this approach leaves the transition rate as unspecified as possible, relying on the proportionality assumption and appropriate specification of the functional form for the influence of covariates. As Blossfeld, Golsch, and Rohwer (2007) highlight, theory in the social sciences for selecting the appropriate parametric model is underdeveloped; thus, semiparametric models offer a useful alternative, particularly when primary interest is on the magnitude and direction of the observed covariates.

$$
\operatorname{ADOPT}_{i t}=h(t) * \exp \left(\beta_{k}\left(x_{i t}\right) \alpha\right) .
$$

Our empirical model is specific to state $i$, and year $t$. ADOPT is our primary outcome variable of interest, the transition rate of adoption for each policy respectively_Eminent Scholars, University Research Grants, and Centers of Excellence. This dichotomous variable is coded 1 in the year a state adopts one of the three respective science policies and 0 in the years leading up to the adoption. ${ }^{7}$ While data on the dollar amount of expenditures for these programs would provide a more ideal dependent variable, the most information that we have is the year of adoption for each of the three programs. The unspecified baseline rate is $h(t)$, and $\left(\beta_{k}\left(x_{i t}\right)\right.$ is a vector of covariates. Table 9.3 lists the variables, functional forms, and sources of the covariates considered in this analysis; each is considered in turn.

Building off Berry and Berry's (1990) study on state lottery adoptions, we include a series of economic and political variables in the analysis. First, we include Fiscal, which estimates the rate of growth in the state's revenue. This measure estimates the state's slack resources and ability to afford science

6. While hazard models are prominently used to estimate transition rates, scholars from a variety of fields have been using these methods to estimate other types of transitions prominent in labor market studies, social inequality studies, demographic analyses, sociological mobility studies, and state policy diffusion (Blossfeld, Golsch, and Rohwer 2007). We follow the literature on the latter and employ an event history model (Berry and Berry 1990; Mintrom and Vergari 1996; True and Mintrom 2001; Volden 2006; Karch 2007).

7. As is characteristic of hazard models, observations beyond the initial year of adoption for states with the policy of interest are dropped. 


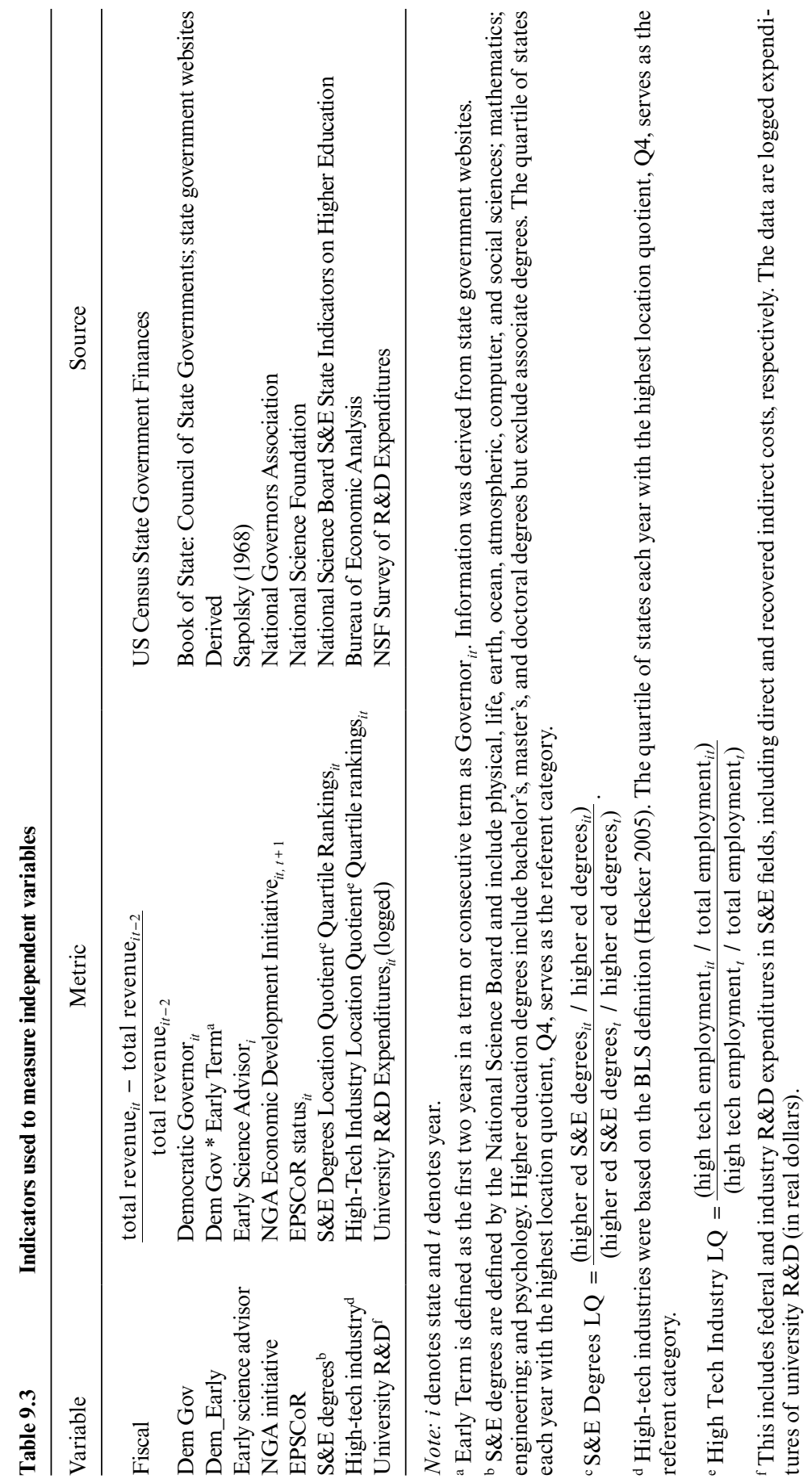


programs. Dem Gov is a binary variable coded 1 in the years the state government inaugurates or has a democratic governor and 0 otherwise. In addition, politicians often have greater political influence when they are initially elected to office. We include a binary variable indicating whether the democratic governor is in his/her first or second year in office_-Dem_Early. In the event the governor is reelected, we only code the first two years in nonconsecutive terms in office as 1 .

The time frame for this analysis begins in 1982 and continues through 2009 for states that have not adopted the respective policy. We begin in the early 1980s, as this marks a time when increased federal and state attention was directed to university-based $\mathrm{R} \& \mathrm{D}$ activity. This coincided with the passage of the Bayh-Dole Act of 1980. With the exception of three state policy adoptions, it is after 1980 that we witness the diffusion of university-based R\&D policy activity. State attention to science issues, however, did not begin at this time. In earlier reviews of state and local science policy actions, Sapolsky $(1968,1971)$ identified twelve states that established general science advisory units. ${ }^{8}$ While other states were considering similar positions in the late 1960 s, these states demonstrated an active interest in state science policy by implementing a science advisory position that mirrored the position in the federal government. We have created a binary, time-invariant, variable for this subset of states-Early Science Advisor-and anticipate that states with this demonstrated record supporting science issues are more likely to adopt these university-based R\&D programs.

We have created a binary variable - NGA Initiative — coded 1 in the year the first three initiatives focused on economic development and R\&D (mentioned above) were presented and the following year, as we expect there may be some lag in policy implementation. The most recent initiative, presented by Governor Heineman in 2011, falls outside the time frame of this analysis.

In addition, we include three state-level benchmarking measures that capture the S\&T capacity of the state-EPSCoR, High Tech Industry, and S\&E Degrees. EPSCoR is a dichotomous variable that denotes the status of the state in the Experimental Program to Stimulate Competitive Research (EPSCoR) program. Administered by NSF, EPSCoR is a federal program that began in 1980 to support and encourage disadvantaged states to improve their research and development activity (Hauger 2004). As of 2009, twenty-five states have received EPSCoR status. The first cohort of EPSCoR states in 1980 included Arkansas, Maine, Montana, South Carolina, and West Virginia. A second cohort was added in 1985: Alabama, Kentucky, Nevada, North Dakota, Oklahoma, Vermont, and Wyoming. The third cohort of states was added in 1987 and included Idaho, Louisiana, Mississippi, and South Dakota. In 1992, Kansas and Nebraska joined. Between 2001 and 2009, seven additional states have been added: Alaska, 
Hawaii, and New Mexico in 2001; Delaware and Tennessee in 2003; New Hampshire in 2005; and Utah in 2009. ${ }^{9}$

High Tech Industry measures the annual high-tech employment for a state. To compute this indicator, we use the Bureau of Labor Statistics definition of high-tech industries (Hecker 2005), ${ }^{10}$ and compute the ratio of high-tech employment to total employment. S\&E Degrees measures the extent to which the state's higher education graduates are concentrated in the fields of science and engineering (S\&E). This measure is drawn from the National Science Board's S\&E State Indicators on Higher Education activity and estimates the ratio of S\&E graduates to total graduates. To estimate benchmarking activity, we compute quartile rankings of the state location quotients for these two state R\&D-related measures (High Tech Industry and S\&E Degrees). For computation of the location quotient, the national ratio serves as the reference base in the denominator. The fourth quartile of the location quotients - the cohort of states with the highest rankingsserves as the referent category for both sets of variables. These values vary by states and year.

We also include a set of federal and industry metrics to account for national R\&D-related trends. We expect that the larger, external spending environment will influence state science policy activity. University R\&D denotes the sum of federal and industry investment in each specific state's university research activity. Given that the three university programs have different aims, we adjust the source of R\&D for this measure. Eminent Scholars and University Research Grants programs are designed to support earlier stage, more upstream R\&D activity; therefore, for the variable University $R \& D$ we include the federal investment in university $R \& D$ for these two sets of models. The Centers of Excellence program aims to support later-stage university $R \& D$ activity that should be more responsive to industry R\&D investment. Thus, we include industry investments in university $R \& D$ for this model. Although we are unable to discern the precise direction of causality in this analysis, these measures approximate whether federal or industry university R\&D investment in a given state complements or substitutes that state's university science policy adoption activity.

Table 9.4 provides descriptive statistics for the covariates for the years leading up to and including the initial year of adoption. While the same set of covariates is used for each of the three models, we present three sets of descriptive statistics given the variation in the cohort of states that have

9. Three additional states have received EPSCoR status after 2009: Rhode Island in 2010, Iowa in 2011, and Missouri in 2012.

10. Hecker's classification of high-tech industries is used for the National Science Board's definition of high-tech sectors, and therefore serves as a valid source for defining the list of NAICS and SIC codes that constitute high-technology industries. Using employment data from the Bureau of Economic Analysis (BEA), we matched Hecker's list by industry title to the BEA's LineCode classification scheme at the three-digit industry. 


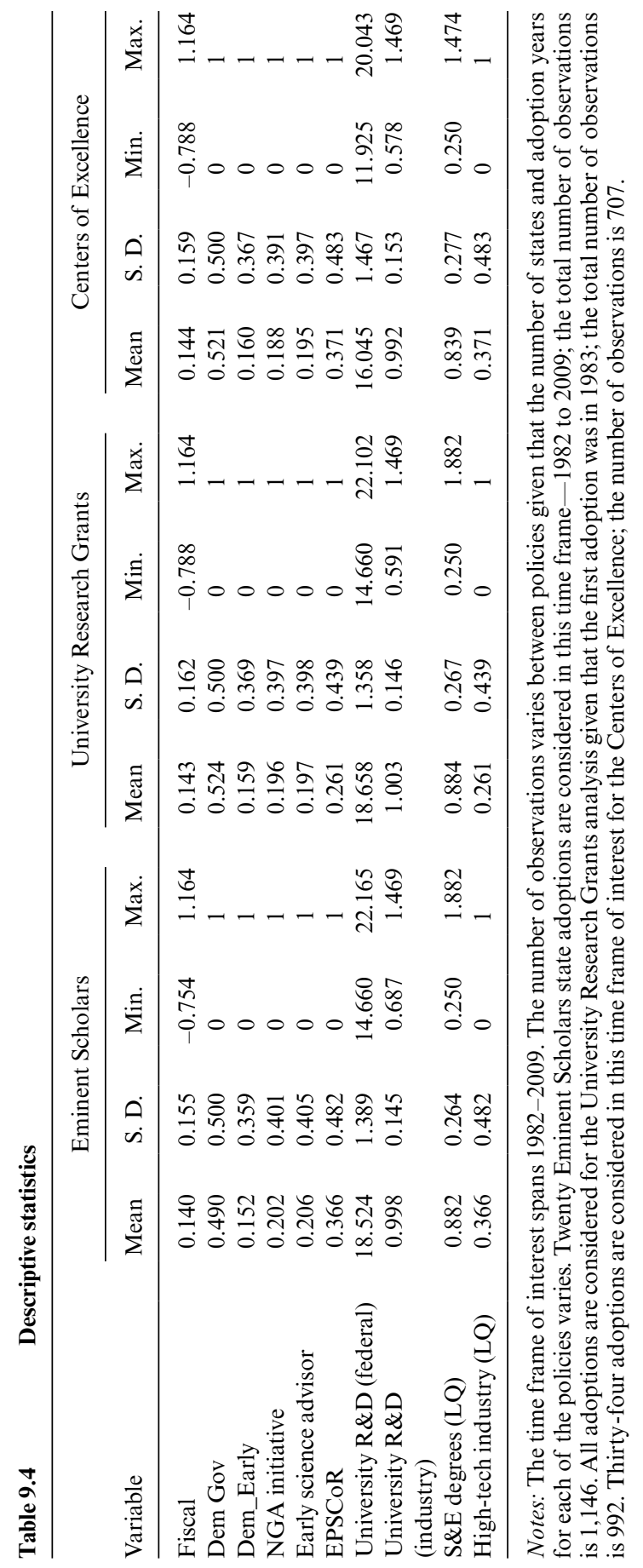


adopted each of these three programs over the time frame of interest. As of 2009, twenty-one states have adopted the Eminent Scholars program; however, twenty adoptions are considered in this analysis. Virginia is leftcensored with initial adoption of the program in 1964. The total number of observations for Eminent Scholars is 1,146. As of 2009, twenty-nine states have adopted the University Research Grants program. All adoptions are considered in this analysis given that the first adoption was in 1983; the total number of observations is 992 . As of 2009, thirty-seven states have adopted a Centers of Excellence program; however, four adoptions are leftcensored-AL (1965), CT (1975), NC (1980), and MI (1981). Thirty-four adoptions are considered in this time frame of interest; the number of observations is 707 .

Table 9.5 provides the correlation coefficients for the covariates. University R\&D (Industry) and University R\&D (Federal) have a high correlation, 0.8959 , however, only one of these measures is used in each of the models to control for external R\&D-University R\&D (Industry) for the Centers of Excellence and University R\&D (Federal) for the Eminent Scholars and University Research Grants programs.

We estimate three sets of Cox proportional hazard models for the policies - one for the Eminent Scholars, University Research Grants, and Centers of Excellence programs, respectively. Additional specification tests were run to ensure validity of the proportionality assumption and goodness of fit. Regarding the former, the results hold for the covariates in the three sets of models with the exception of the first quartile ranking of S\&E Degrees (Q1) and the third quartile ranking of High Tech Industry (Q3) for the Centers of Excellence program. Both of these variables were significant in the specification tests with $p$-values of 0.048 and 0.037 , respectively. Given this limitation, we exert caution in our interpretation of these coefficients in the Center of Excellence model as the values for these two are likely problematic.

\subsection{Empirical Results}

Tables 9.6, 9.7, and 9.8 present the results of the Cox proportional hazard models for the three state science policy programs. For ease of interpretation and discussion of results across the three policies, the coefficients are reported indicating the direction of the hazard rate to adopt. ${ }^{11}$ Model 1 provides a baseline with economic and political covariates (Fiscal, Dem Gov, and Dem_Early). Model 2 includes state science policy variables (NGA Initiative and Early Science Advisor) and Models 3, 4, and 5 add in the benchmarking and R\&D-related covariates (EPSCoR, University R\&D, S\&E Degrees, and High Tech Industry). The empirical results for each policy are discussed in turn.

11. Conversion of the coefficient, $\beta_{k}$, to the hazard rate: Hazard Rate $=\left(\exp \left(\beta_{k}\right)-1\right) * 100 \%$. 


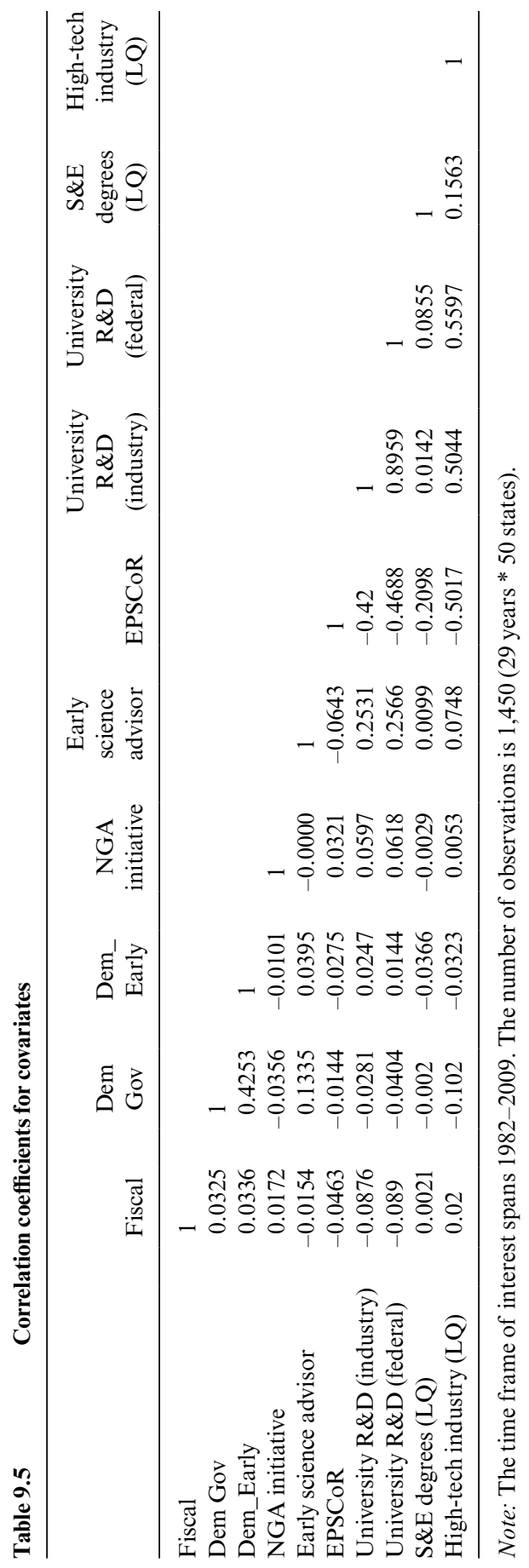


Table 9.6 Empirical results of Eminent Scholars policy adoption

\begin{tabular}{|c|c|c|c|c|c|}
\hline Variables & $\begin{array}{l}\text { ES } \\
(1)\end{array}$ & $\begin{array}{l}\text { ES } \\
(2)\end{array}$ & $\begin{array}{l}\text { ES } \\
(3)\end{array}$ & $\begin{array}{l}\text { ES } \\
\text { (4) }\end{array}$ & $\begin{array}{l}\text { ES } \\
(5)\end{array}$ \\
\hline Fiscal & $\begin{array}{l}2.376^{* *} \\
(1.033)\end{array}$ & $\begin{array}{l}2.799 * * \\
(1.095)\end{array}$ & $\begin{array}{l}2.860^{* *} \\
(1.114)\end{array}$ & $\begin{array}{l}3.727^{* * *} \\
(1.359)\end{array}$ & $\begin{array}{l}3.717 * * * \\
(1.386)\end{array}$ \\
\hline Dem Gov & $\begin{array}{c}0.515 \\
(0.482)\end{array}$ & $\begin{array}{c}0.533 \\
(0.485)\end{array}$ & $\begin{array}{c}0.450 \\
(0.489)\end{array}$ & $\begin{array}{c}0.366 \\
(0.499)\end{array}$ & $\begin{array}{c}0.250 \\
(0.518)\end{array}$ \\
\hline Dem_Early & $\begin{array}{c}-0.825 \\
(0.795)\end{array}$ & $\begin{array}{c}-1.048 \\
(0.802)\end{array}$ & $\begin{array}{l}-1.002 \\
(0.806)\end{array}$ & $\begin{array}{c}-1.063 \\
(0.804)\end{array}$ & $\begin{array}{c}-1.051 \\
(0.806)\end{array}$ \\
\hline NGA initiative & & $\begin{array}{c}-0.476 \\
(0.541)\end{array}$ & $\begin{array}{l}-0.515 \\
(0.547)\end{array}$ & $\begin{array}{c}-0.595 \\
(0.573)\end{array}$ & $\begin{array}{c}-0.596 \\
(0.579)\end{array}$ \\
\hline Early science advisor & & $\begin{array}{l}1.556^{* * *} \\
(0.459)\end{array}$ & $\begin{array}{l}1.831^{* * *} \\
(0.508)\end{array}$ & $\begin{array}{l}2.243^{* * *} \\
(0.536)\end{array}$ & $\begin{array}{l}2.162 * * * \\
(0.554)\end{array}$ \\
\hline EPSCoR & & & $\begin{array}{c}-1.137^{*} \\
(0.625)\end{array}$ & $\begin{array}{l}-1.994^{* * *} \\
(0.735)\end{array}$ & $\begin{array}{l}-2.017^{* * *} \\
(0.762)\end{array}$ \\
\hline $\begin{array}{l}\text { University R\&D } \\
\text { (federal) }\end{array}$ & & & $\begin{array}{c}-0.444^{*} \\
(0.251)\end{array}$ & $\begin{array}{c}-0.429 \\
(0.275)\end{array}$ & $\begin{array}{l}-0.445 \\
(0.294)\end{array}$ \\
\hline SE degrees Q1 & & & & $\begin{array}{l}2.666^{* * *} \\
(0.922)\end{array}$ & $\begin{array}{l}2.427^{* * *} \\
(0.934)\end{array}$ \\
\hline SE degrees Q2 & & & & $\begin{array}{l}1.913^{* *} \\
(0.869)\end{array}$ & $\begin{array}{c}1.599^{*} \\
(0.897)\end{array}$ \\
\hline SE degrees Q3 & & & & $\begin{array}{c}0.619 \\
(0.865)\end{array}$ & $\begin{array}{c}0.541 \\
(0.871)\end{array}$ \\
\hline High-tech industry Q1 & & & & & $\begin{array}{c}-0.049 \\
(0.957)\end{array}$ \\
\hline High-tech industry Q2 & & & & & $\begin{array}{c}0.689 \\
(0.804)\end{array}$ \\
\hline High-tech industry Q3 & & & & & $\begin{array}{c}0.554 \\
(0.686)\end{array}$ \\
\hline
\end{tabular}

Notes: Cox proportional hazard model was run with adoption of the Eminent Scholars program serving as the transition indicator. The coefficients, $\beta_{k}$ are reported indicating the direction of the hazard ratio. The number of observations is 1,146 . Twenty state adoptions are considered in these models; Virginia was left-censored due to early adoption in 1964. Standard errors are in parentheses.

***Significant at the 1 percent level.

**Significant at the 5 percent level.

*Significant at the 10 percent level.

\subsubsection{Eminent Scholar Results}

Table 9.6 reports the coefficients from equation (1) for the Eminent Scholars program. The effect of the state fiscal growth (Fiscal) is positive and statistically significant. States exhibiting a growth in revenue increases adoption activity. The political covariates (Dem Gov and Dem_Early) are not statistically significant. Among the two state science policy covariates, the coefficients for Early Science Advisor are positive and significant. The cohort of twelve states that initially adopted state science policy units in the 1960s is more likely to adopt the Eminent Scholars program than those that did not have this position. 
Turning to the set of benchmarking and R\&D-related measures, the EPSCoR coefficient is statistically significant and negative demonstrating that lagging states in terms of R\&D performance are less likely to try to attract eminent scholars. To reiterate, states receive EPSCoR status if their R\&D performance falls below a minimum threshold. In other words, states without an EPSCoR status are more likely to adopt the Eminent Scholars program than those with the status. The negative coefficient for University $\mathrm{R} \& \mathrm{D}$ is weakly significant in Model 3 ( $p$-value $<0.1$ ) and not robust across Models 4 and 5.

The coefficients for S\&E Degrees are positive and statistically significant for Quartile 1 and Quartile 2. In contrast to the referent category-Quartile 4, the cohort of states with the largest location quotients-states with lagging concentrations of $\mathrm{S} \& \mathrm{E}$ graduates are more likely to have this program. The size of the coefficients from the quartile dummies, notably Q1 and Q2, indicate that the likelihood to adopt the Eminent Scholars program increases as states fall in rank. Taken at first glance, this stands in contrast to the implications from the EPSCoR coefficients; this is discussed in greater detail following the discussion section. Lastly, the coefficients for the quartile rankings of High Tech Industry are not statistically significant.

\subsubsection{University Research Grant Results}

Table 9.7 reports the coefficients for the Cox proportional hazard model for the University Research Grants program. A number of the state R\&D coefficients mirror the results from the Eminent Scholars model. Most notably, the coefficients for Early Science Advisor are positive and statistically significant across Models 2-5. Moreover, states with an EPSCoR status are less likely to adopt the Eminent Scholars program - as indicated by the negative and statistically significant coefficients. As for the benchmarking measure S\&E Degrees, Quartile 1 is positive and statistically significant, though the effect is statistically insignificant for the two other quartiles. Regarding similarities in terms of insignificant results, the political variables (Dem Gov and Dem_Early) and NGA Initiative are statistically insignificant for this set of models.

In contrast to the Eminent Scholars results, however, the coefficients for Fiscal are not statistically significant. Results for University R\&D are robust - negative and statistically significant. As federal investment in university $R \& D$ within states increases, the likelihood of states adopting the University Research Grants decreases. While we anticipated state policy decisions to complement external — notably federal - investment in university $\mathrm{R} \& \mathrm{D}$, these results suggest a substitutive relationship, or crowding-out effect; this is discussed at greater length in the discussion section. Turning to the last set of benchmarking measures, the coefficient for Q1 for High Tech Industry is negative and statistically significant. Again, the fourth quartilethose states with the highest location quotients - serves as the referent cate- 
Table 9.7

Empirical results of University Research Grants policy adoption

\begin{tabular}{|c|c|c|c|c|c|}
\hline Variables & $\begin{array}{l}\text { URG } \\
\text { (1) }\end{array}$ & $\begin{array}{l}\text { URG } \\
\text { (2) }\end{array}$ & $\begin{array}{l}\text { URG } \\
\text { (3) }\end{array}$ & $\begin{array}{l}\text { URG } \\
\text { (4) }\end{array}$ & $\begin{array}{l}\text { URG } \\
\text { (5) }\end{array}$ \\
\hline Fiscal & $\begin{array}{c}1.267 \\
(0.804)\end{array}$ & $\begin{array}{l}1.317 \\
(0.839)\end{array}$ & $\begin{array}{c}1.269 \\
(0.860)\end{array}$ & $\begin{array}{l}1.358 \\
(0.919)\end{array}$ & $\begin{array}{c}1.412 \\
(0.973)\end{array}$ \\
\hline Dem Gov & $\begin{array}{c}0.270 \\
(0.389)\end{array}$ & $\begin{array}{c}0.214 \\
(0.392)\end{array}$ & $\begin{array}{c}0.109 \\
(0.400)\end{array}$ & $\begin{array}{c}0.121 \\
(0.408)\end{array}$ & $\begin{array}{c}0.316 \\
(0.419)\end{array}$ \\
\hline Dem_Early & $\begin{array}{l}-0.350 \\
(0.576)\end{array}$ & $\begin{array}{l}-0.311 \\
(0.577)\end{array}$ & $\begin{array}{l}-0.244 \\
(0.581)\end{array}$ & $\begin{array}{c}-0.346 \\
(0.584)\end{array}$ & $\begin{array}{c}-0.466 \\
(0.588)\end{array}$ \\
\hline NGA initiative & & $\begin{array}{c}0.117 \\
(0.408)\end{array}$ & $\begin{array}{c}0.091 \\
(0.416)\end{array}$ & $\begin{array}{c}0.091 \\
(0.420)\end{array}$ & $\begin{array}{c}0.108 \\
(0.424)\end{array}$ \\
\hline Early science advisor & & $\begin{array}{l}0.794 * * \\
(0.400)\end{array}$ & $\begin{array}{l}1.322 * * * \\
(0.430)\end{array}$ & $\begin{array}{l}1.467 * * * \\
(0.454)\end{array}$ & $\begin{array}{l}1.571^{* * *} \\
(0.455)\end{array}$ \\
\hline EPSCoR & & & $\begin{array}{l}-1.292^{* * *} \\
(0.498)\end{array}$ & $\begin{array}{l}-1.631^{* * *} \\
(0.532)\end{array}$ & $\begin{array}{l}-1.226^{* *} \\
(0.545)\end{array}$ \\
\hline $\begin{array}{l}\text { University R\&D } \\
\text { (federal) }\end{array}$ & & & $\begin{array}{l}-0.710 * * * \\
(0.187)\end{array}$ & $\begin{array}{l}-0.779 * * * \\
(0.196)\end{array}$ & $\begin{array}{l}-1.113 * * * \\
(0.237)\end{array}$ \\
\hline SE degrees Q1 & & & & $\begin{array}{l}1.063^{* *} \\
(0.510)\end{array}$ & $\begin{array}{l}1.229^{* *} \\
(0.577)\end{array}$ \\
\hline SE degrees Q2 & & & & $\begin{array}{c}-0.027 \\
(0.609)\end{array}$ & $\begin{array}{c}-0.075 \\
(0.633)\end{array}$ \\
\hline SE degrees Q3 & & & & $\begin{array}{c}0.103 \\
(0.545)\end{array}$ & $\begin{array}{c}0.452 \\
(0.573)\end{array}$ \\
\hline High-tech industry Q1 & & & & & $\begin{array}{l}-2.097 * * * \\
(0.723)\end{array}$ \\
\hline High-tech industry Q2 & & & & & $\begin{array}{c}-0.754 \\
(0.644)\end{array}$ \\
\hline High-tech industry Q3 & & & & & $\begin{array}{c}-0.727 \\
(0.533)\end{array}$ \\
\hline
\end{tabular}

Notes: Cox proportional hazard model was run with adoption of the University Research Grants program serving as the transition indicator. The coefficients, $\beta_{k}$ are reported indicating the direction of the hazard ratio. The number of observations is 992 . Twenty-nine state adoptions are considered in these models; every state is initially considered in this model. Standard errors are in parentheses.

***Significant at the 1 percent level.

**Significant at the 5 percent level.

*Significant at the 10 percent level.

gory. In contrast to states that lead in terms of high-tech industrial capacity, states ranked in the lowest quartile are less likely to adopt the University Research Grants program. In other words, this suggests that states leading along this measure are more likely to adopt the program than those that lag.

\subsubsection{Centers of Excellence Results}

Table 9.8 presents the results of equation (1) for the Centers of Excellence program. There is notable overlap in the results with the University Research Grants program, though the results are not as robust with this program. The effect for the Early Science Advisor is positive and statisti- 
Table 9.8 Empirical results of Centers of Excellence policy adoption

\begin{tabular}{|c|c|c|c|c|c|}
\hline Variables & $\begin{array}{l}\text { CE } \\
\text { (1) }\end{array}$ & $\begin{array}{l}\text { CE } \\
(2)\end{array}$ & $\begin{array}{l}\text { CE } \\
\text { (3) }\end{array}$ & $\begin{array}{l}\mathrm{CE} \\
(4)\end{array}$ & $\begin{array}{l}\mathrm{CE} \\
(5)\end{array}$ \\
\hline Fiscal & $\begin{array}{l}1.011 \\
(0.877)\end{array}$ & $\begin{array}{c}1.061 \\
(0.879)\end{array}$ & $\begin{array}{c}1.087 \\
(0.920)\end{array}$ & $\begin{array}{c}1.196 \\
(0.975)\end{array}$ & $\begin{array}{c}1.408 \\
(1.107)\end{array}$ \\
\hline Dem Gov & $\begin{array}{c}-0.048 \\
(0.404)\end{array}$ & $\begin{array}{l}-0.040 \\
(0.405)\end{array}$ & $\begin{array}{c}-0.273 \\
(0.419)\end{array}$ & $\begin{array}{c}-0.308 \\
(0.425)\end{array}$ & $\begin{array}{c}-0.051 \\
(0.464)\end{array}$ \\
\hline Dem_Early & $\begin{array}{c}0.489 \\
(0.499)\end{array}$ & $\begin{array}{c}0.449 \\
(0.501)\end{array}$ & $\begin{array}{c}0.405 \\
(0.502)\end{array}$ & $\begin{array}{c}0.344 \\
(0.505)\end{array}$ & $\begin{array}{c}0.251 \\
(0.505)\end{array}$ \\
\hline NGA initiative & & $\begin{array}{l}-0.375 \\
(0.464)\end{array}$ & $\begin{array}{c}-0.258 \\
(0.471)\end{array}$ & $\begin{array}{c}-0.236 \\
(0.472)\end{array}$ & $\begin{array}{c}-0.249 \\
(0.474)\end{array}$ \\
\hline Early science advisor & & $\begin{array}{c}0.294 \\
(0.409)\end{array}$ & $\begin{array}{c}0.504 \\
(0.416)\end{array}$ & $\begin{array}{c}0.593 \\
(0.435)\end{array}$ & $\begin{array}{l}0.984^{* *} \\
(0.473)\end{array}$ \\
\hline EPSCoR & & & $\begin{array}{c}-1.074^{* *} \\
(0.421)\end{array}$ & $\begin{array}{l}-1.290^{* * *} \\
(0.454)\end{array}$ & $\begin{array}{c}-0.322 \\
(0.513)\end{array}$ \\
\hline $\begin{array}{l}\text { University R\&D } \\
\text { (industry) }\end{array}$ & & & $\begin{array}{l}-0.370^{* * *} \\
(0.118)\end{array}$ & $\begin{array}{l}-0.416^{* * *} \\
(0.126)\end{array}$ & $\begin{array}{l}-0.738^{* * *} \\
(0.160)\end{array}$ \\
\hline SE degrees Q1 & & & & $\begin{array}{c}0.665 \\
(0.498)\end{array}$ & $\begin{array}{c}0.910 \\
(0.567)\end{array}$ \\
\hline SE degrees Q2 & & & & $\begin{array}{c}0.303 \\
(0.503)\end{array}$ & $\begin{array}{c}0.755 \\
(0.550)\end{array}$ \\
\hline SE degrees Q3 & & & & $\begin{array}{c}-0.136 \\
(0.560)\end{array}$ & $\begin{array}{c}0.319 \\
(0.575)\end{array}$ \\
\hline High-tech industry Q1 & & & & & $\begin{array}{l}-2.646^{* * *} \\
(0.758)\end{array}$ \\
\hline High-tech industry Q2 & & & & & $\begin{array}{l}-0.661 \\
(0.655)\end{array}$ \\
\hline High-tech industry Q3 & & & & & $\begin{array}{c}-0.607 \\
(0.543)\end{array}$ \\
\hline
\end{tabular}

Notes: Cox proportional hazard model was run with adoption of the Centers of Excellence program serving as the transition indicator. The coefficients, $\beta_{k}$ are reported indicating the direction of the hazard ratio. The number of observations is 707 . Thirty-four state adoptions are considered in these models; Alabama, Connecticut, North Carolina, and Michigan are left-censored due to early adoption prior to 1982. Standard errors are in parentheses.

*** Significant at the 1 percent level.

**Significant at the 5 percent level.

*Significant at the 10 percent level.

cally significant, though the effect only holds for the full model (Model 5). As for EPSCoR, the coefficients are negative and significant for Models 3 and 4; however, the results are not robust in the full model. Regarding external R\&D - notably industry investment in university R\&D - the coefficients for University $R \& D$ are negative and statistically significant across all models. Again, we had expected a positive effect; the implications of this are discussed in the next section. Lastly, the effect on High Tech Industry is negative and statistically significant for Quartile 1. As with the University Research Grants results, the results are not significant for the other rankings. 
The remaining covariates are statistically insignificant. Notably, as with both the results for the Eminent Scholars and University Research Grants, the political variables and the NGA Initiative do not show signs of statistical significance.

\subsection{Discussion}

This analysis presents the results from three empirical models to identify factors associated with the adoption of the Eminent Scholars, University Research Grants, and Centers of Excellence programs. As mentioned above, this analysis serves as an exploratory exercise to identify trends with state policy-making activity rather than claiming causality. The results for each policy offers insight on the factors associated with the state adoptions.

For the Eminent Scholars program, the results provide evidence to suggest that states leading in terms of $R \& D$ interest and activity are more likely to adopt the program. This is made evident from the results on the Early Science Advisor and EPSCoR variables. The former offers evidence to suggest that states that have demonstrated an early interest in state science policy are more likely to adopt the program. The latter highlights an association between state R\&D capacity and the program. To reiterate, the Eminent Scholars program is a more upstream policy - in contrast to the Centers of Excellence - requiring substantial up-front costs to invest in distinguished research scientists and their labs. These earlier-stage investments are made with the expectation that the researchers will recover the costs as they develop their research and commercialize. The results for Fiscal, therefore, are not surprising, as states with fiscal growth are more likely to adopt this program. States exhibiting an increase in revenue have greater slack resources and are able to afford the program with longer-term returns on investments. Taken together, these results suggest that states rely on their $\mathrm{R} \& \mathrm{D}$ capacity as they invest in this program. This policy adoption can be viewed as states building upon their demonstrated strengths when considering this more upstream policy.

The results for the benchmarking measure, S\&E Degrees, at first glance appear to stand in contrast to these conclusions. The positive coefficient for Quartile 1 indicates that states with a lagging ratio of S\&E higher-education graduates are more likely to have the program. We might expect the direction of the coefficient to have the opposite sign, given the implications from the other variables that suggest that $R \& D$ capacity is associated with this policy adoption. In looking at the distribution of the S\&E Degrees measure more closely, these results affirm what scholars already know about the complexity of the R\&D process: strength along one dimension of R\&D does not necessarily ensure strength along another. To better understand the distribution of the S\&E Degrees quartile rankings, we consider it in contrast to the distribution of High Tech Industry quartile rankings; the former measure offers 
S\&E Degrees
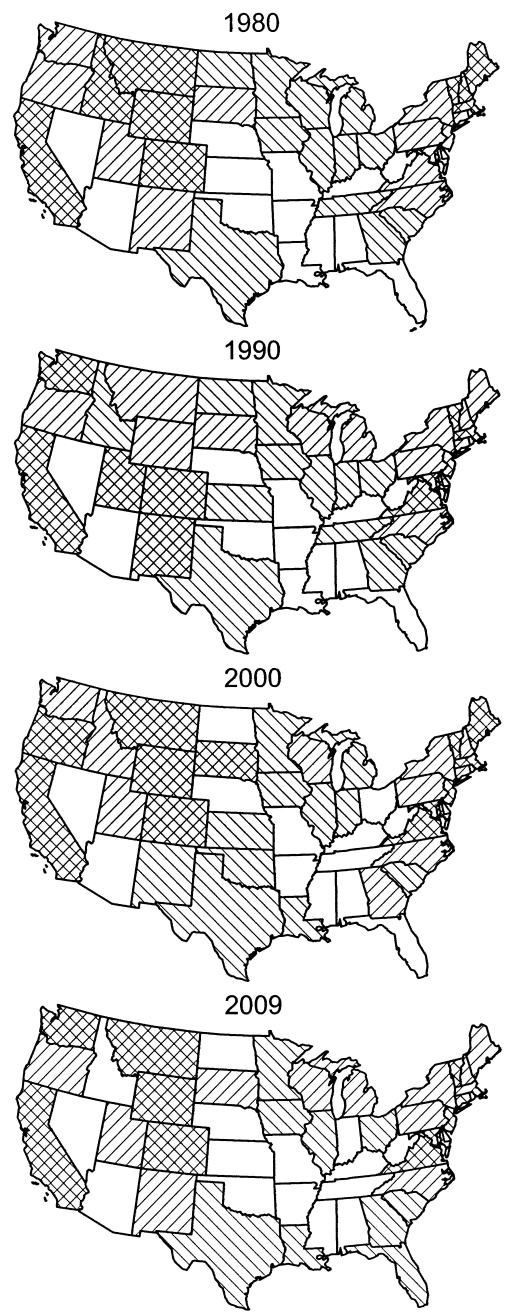

High Tech Industry
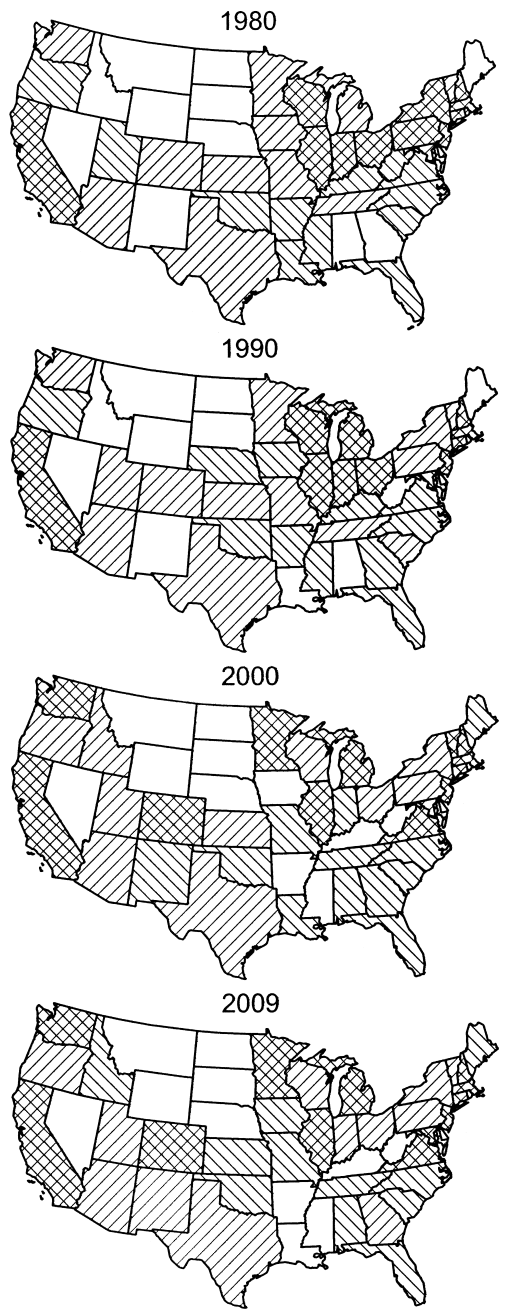

Quartile Rating

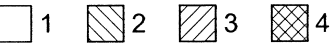

Fig. 9.1 Quartile rankings of S\&E degrees and high-tech industry for 1980, 1990, 2000, and 2009

a more upstream measure of $R \& D$ capacity, while the high-tech measure is more downstream. Figure 9.1 presents a series of maps of these two measures showing how these measures have changed over the past forty years.

Most notably the leading cohorts of states for both measures vary. The left column in figure 9.1 illustrates a general trend that the states with leading 
ratios of S\&E Degrees are concentrated along the West Coast and Rocky Mountain region, with a few located in New England and in the mid-Atlantic region. The lagging states demonstrate a greater concentration in the plains and Southeast. California, New York, Virginia, Maryland, and Washington are among the leaders along this measure, which is not surprising given their history of demonstrated $\mathrm{R} \& \mathrm{D}$ and economic performance. What is more unexpected, however, is the group of EPSCoR states - including Montana, Wyoming, Vermont, and Maine - that lead along this dimension as well. While the latter cohort lags in terms of its relative share of R\&D activitywhich qualifies them for EPSCoR status - these states produce a greater ratio of S\&E degrees compared to the US average. This figure illustrates that the concentration of S\&E Degrees is more varied and does not directly align with more traditional, downstream measures of R\&D.

The more traditional, downstream activity is illustrated in the right column in figure 9.1. These maps of High Tech Industry more closely mirror the overall economic health of the state. This is illustrated by the notable concentration in the Rust Belt region in the 1980s and 1990s, followed by a shift to mid-Atlantic states and Washington, Colorado, Illinois, and Minnesota in the more recent decades.

Turning to the University Research Grants program, there is notable overlap for some of the coefficients with the results from the Eminent Scholars program. In particular, results for the Early Science Advisor and EPSCoR covariates similarly suggest that states with a demonstrated R\&D capacity are more likely to adopt the University Research Grants program. Like the Eminent Scholars program, this is a more upstream program focused on university research with the expectation that the public investment will bolster capacity and yield returns in the longer term. This conclusion is additionally supported by the negative coefficient for Quartile 1 of the High Tech Industry covariate. State interest and investment in this program can be viewed as an effort to build upon their demonstrated strengths of more downstream $\mathrm{R} \& \mathrm{D}$ measures. As for the positive coefficient for Quartile 1 of the S\&E Degrees covariate, it is important to take into consideration the distribution of the variable - as is highlighted above. It is important to recognize that the rankings along this more upstream measure do not directly correlate with common, more downstream perceptions of state R\&D capacity.

While the negative coefficient for University R\&D was only significant in Model 3 for the Eminent Scholars, these coefficients were robust for the University Research Grants models. Originally, we anticipated that the relationship between federal investment in university $R \& D$ would be positively associated with the adoption of the University Research Grants program. This relationship, in fact, suggests the opposite effect. This suggests that states are less likely to adopt the University Research Grants program when federal investment in university R\&D increases. Another way to look at this is that states tend to adopt when federal investment in university R\&D 
decreases, pointing toward a crowding-out or substitutive effect. A substantial portion of the federal budget for university R\&D is discretionary and historical trends of spending have been tenuous (Teich 2009). With annual threats to cut the federal R\&D budget, this state science policy activity can be viewed as a proactive effort to provide public investment for university $R \& D$. This suggests that states are not necessarily mirroring federal $R \& D$ actions, but rather are responding to decreases in federal spending by taking an active stance to support this program.

Results for the Centers of Excellence program are not as robust as the other two models. The coefficient for the Early Science Advisor is only positive and significant in the full model, though the coefficient for EPSCoR loses significance in the full model. While the effect is stronger for the other two policies, we interpret these weaker results to suggest that this program appeals to a broader cohort of states, not necessarily those with a demonstrated science capacity. States with an early, demonstrated interest in science and non-EPSCoR states are likely to have the program; however, the weak results indicate that even more states tend to adopt this program. The Centers of Excellence program stands out in contrast to the other two programs given that it is a later-stage, more downstream program. In other words, this program appears to attract broader appeal given that the investment is closer to more immediate, tangible, and economic outcomes. The negative coefficient on the High Tech Industry quartile (Q1) lends credence to this conclusion as well. States are cognizant of the strength of their R\&D capacity - in terms of more downstream measures - when they consider adopting the Centers of Excellence program, which is centered on university and industry collaborations. Our interpretations of the negative coefficients on University $R \& D$ variables mirror the discussion with the University Research Grants program. While we anticipated a complementary association, the results indicate the opposite. We interpret this to suggest that states adopt this university-based R\&D program when external support is lacking, demonstrating a bottom-up commitment from states.

Looking across the three programs, we see some overlap between the Eminent Scholars and University Research Grants programs and between the University Research Grants and Centers of Excellence programs. The former pair of policies is a set of more upstream investments in university R\&D. Results suggest that states seek to build upon their strengths when making these investments. State commitment requires a stronger R\&D capacity to offset the more upstream investment. Although there is overlap with the University Research Grants and Centers of Excellence programs, the results are not as robust for the Centers of Excellence. Both policies, in contrast to the Eminent Scholars, have a central research componentwith the former focused on earlier-stage activity and the latter concerned with collaboration between the university and industry. The implications of the weaker results for the Centers of Excellence program suggest that 
the program attracts broader appeal to a larger cohort of states given that it is a program designed to produce more immediate tangible outcomes. In looking at the rate of adoption alone, this is not surprising, as 74 percent of states have adopted this program.

While there are commonalities across the portfolio of programs, the results highlight that state governments rely on a different set of incentives when adopting and maintaining these programs. We attribute these differences to the structure of the state programs with the Eminent Scholars and University Research Grants programs aimed at supporting earlier-stage, more basic university R\&D activity, and the Centers of Excellence program designed to support later-stage R\&D activity. Arguably the more downstream policy has greater appeal since this investment is closer to more tangible, economic outcomes.

\subsubsection{Consideration of the Eminent Scholars, University \\ Research Grants, and Centers of Excellence as a Portfolio}

Thus far, we have focused on each program separately, taking into consideration some of their similarities and differences. Now we briefly consider these programs as part of a larger state university-based science portfolio. In looking at table 9.1, most states have adopted more than one policy. Figure 9.2 presents a series of snapshots of the continental US illustrating the path of diffusion of this portfolio of programs over the past three decades. ${ }^{12}$ By 1990, marking one decade of state policy adoption activity, both North Carolina and Georgia established all three programs; by 2000, New York, Ohio, and South Carolina joined this cohort; and by 2009, five additional states adopted the entire portfolio. ${ }^{13}$ These maps highlight a concentration of state-funded university R\&D programs along the East Coast and Midwest with states in the Southeast, Rust Belt region, and lower Midwest demonstrating greater state policy efforts by adopting more programs. As of 2009, forty-four states had at least one university R\&D policy. Of those, thirty-three had two policies and ten had adopted the entire portfolio.

Table 9.9 presents descriptive statistics for the years of adoption for having a first, second, and third policy, respectively. On average, states adopted one of these policies by 1989-with Virginia leading as the first adopter in 1964 and North Dakota serving as the most recent state to adopt their first state university-based policy in 2006. Of those states with more than one policy, on average, they adopted a second policy by 1996 and a third by 1999 , respectively. For those states with more than one policy, table 9.10 provides information on the time lag between adopting a second and third policy.

12. A map for the baseline year was not included given the dearth of state university R\&D policy activity at this time. In 1980, only four states-AL, CT, NC, and VA - had one of the three programs. Figure 9.1 is intended to reflect the diffusion of adoption, thus the first image of state policy activity is 1990 .

13. These states include: AR, CT, KS, KY, and OK. 

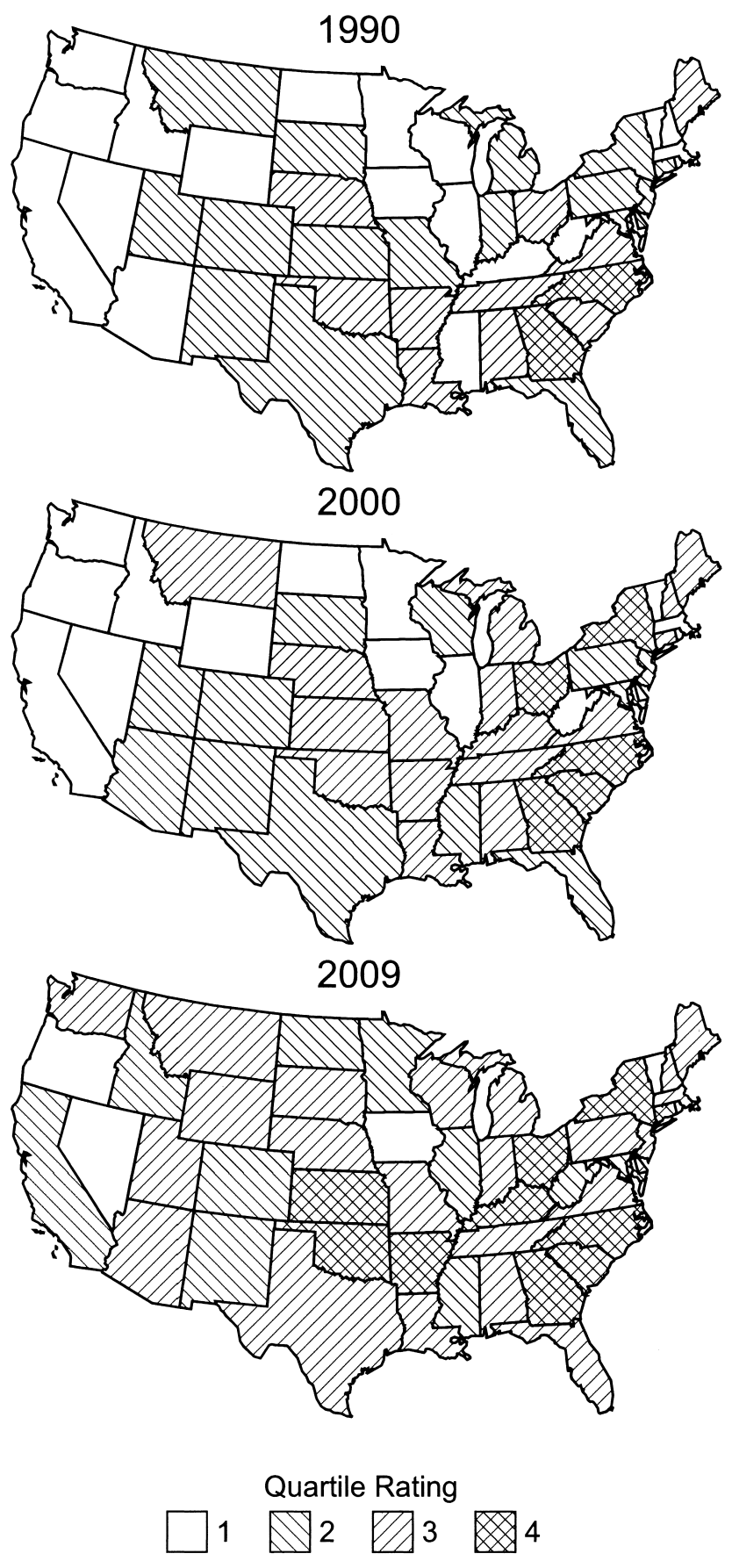

Fig. 9.2 Distribution of state university $R \& D$ portfolio-1990, 2000, and 2009 
Table 9.9

Adoption years for portfolio of state university R\&D programs

\begin{tabular}{lcccc}
\hline & & \multicolumn{3}{c}{ Year adopt (state) } \\
\cline { 3 - 5 } Number of policies & Number of states & Mean & First adopter & Most recent adopter \\
\hline 1 & 44 & 1989 & $1964(\mathrm{VA})$ & $2006(\mathrm{ND})$ \\
2 & 33 & 1996 & $1983(\mathrm{SC})$ & 2009 (MA) \\
3 & 10 & 1999 & $1986(\mathrm{NC})$ & $2006(\mathrm{CT})$ \\
\hline
\end{tabular}

Table 9.10

Duration between policy adoptions within states

\begin{tabular}{lccccc}
\hline Policy time lag & $\begin{array}{c}\text { Number of } \\
\text { states }\end{array}$ & $\begin{array}{c}\text { Mean } \\
\text { (years) }\end{array}$ & $\begin{array}{c}\text { Standard } \\
\text { deviation }\end{array}$ & Min. & Max. \\
\hline First to second & 33 & 9.94 & 8.61 & 0 & 28 \\
Second to third & 9 & 8.56 & 6.67 & 0 & 17 \\
First to third & 9 & 17.11 & 11.37 & 0 & 41 \\
\hline
\end{tabular}

On average, the time lag between adopting the first and second policy was roughly ten years; the average lag decreased slightly to 8.5 years for states between adopting the second and third policy.

\subsection{Reflective Conclusions}

Over the past thirty years, the fifty state governments have experimented with different programs that attempt to leverage academic science to create economic growth. Given the current economic climate and the federal government's tenuous commitment to $\mathrm{R} \& \mathrm{D}$, we are likely to see more state efforts that attempt to leverage science resources for economic development. Most notably, for the more upstream Eminent Scholars and University Research Grants programs, states seek to build upon the strengths of their universities when making this investment. The more downstream Centers of Excellence programs have broader appeal, which is likely due to the fact that the program is designed to produce more immediate tangible outcomes through involvement with industry. It seems also that states that have a historical commitment to science policy have stayed true to this tradition and became early adopters while other states are motivated to adopt science policy as a means to enhance their ranking and leverage their strengths.

This analysis is part of a larger research agenda focused on understanding state science policy. This chapter not only offers greater insight on the typology of state science programs, it serves as an essential first step toward policy evaluation. It is a critical assumption that policy evaluations reliant on natural experiments depend on exogenous policy switches (Shadish, Campbell, and Cook 2002). This chapter takes this assumption seriously. 
Only with this information, will researchers be equipped to begin to assess the efficacy of these programs.

The increased prevalence of these state-based science policies suggests that state policymakers have come to justify support of university R\&D programs under the premise that $\mathrm{R} \& \mathrm{D}$ will stimulate innovation and thereby foster local entrepreneurship and economic growth. The adoption of these policies reflects the prevalence of new expectations for research universities. To the extent that states are investing in university research it is likely that policymakers will expect a return on their investments. Additional analysis and better data is required to see if these policies have had the desired impact. These quantitative analyses serve as an exploratory effort toward understanding whether and how state economic, political, and R\&D-related factors influence the state science policy-making process. The logical next step is to examine their impact.

Public commitment to science research is evident by federal funding; what this research highlights, however, is that this public commitment stems from multiple levels extending to state governments as well. The large-scale adoption of these programs suggests that state experiments with science policy might fruitfully give way to national policies that would level the playing field between states. However, even when the majority of states have adopted the program there are some states that elect not to participate. We hope that with these preliminary efforts that we encourage scholars and policymakers to further investigate state science policies.

\section{References}

Aboelela, S. W., E. Larson, S. Bakken, O. Carrasquillo, A. Formicola, S. A. Glied, J. Hass, and K. M. Gebbie. 2007. "Defining Interdisciplinary Research: Conclusions from a Critical Review of the Literature." Health Services Research 42 (1, pt. 1): 329-46.

Baumgartner, F. R., V. Gray, and D. Lowery. 2009. "Federal Policy Activity and the Mobilization of State Lobbying Organizations." Political Research Quarterly 62 (3): 552-67. doi: 10.1177/1065912908322407.

Berglund, D., and C. Coburn. 1995. Partnerships: A Compenduim of State and Federal Cooperative Technology Programs. Columbus, OH: Battelle Press.

Berry, F. S., and W. D. Berry. 1990. "State Lottery Adoptions as Policy Innovations: An Event History Analysis." American Political Science Review 84 (2): 395-415.

Blossfeld, H.-P., K. Golsch, and G. Rohwer. 2007. Event History Analysis with Stata. Oxford: Taylor \& Francis Group, Psychology Press.

Blume-Kohout, M. E., K. B. Kumar, and N. Sood. 2009. "Federal Life Sciences Funding and University R\&D." NBER Working Paper no. 15146, Cambridge, MA.

Bozeman, B. 2000. "Technology Transfer and Public Policy: A Review of Research and Theory." Research Policy 29:627-55. 
Combes, R. S., and W. J. Todd. 1996. "From Henry Grady to the Georgia Research Alliance: A Case Study of Science-Based Development in Georgia." Annals of the New York Academy of Sciences 798 (1): 59-77. doi: 10.1111/j.1749-6632.1996 .tb24856.x.

Cozzens, S. E., and J. E. Melkers. 1997. "Use and Usefulness of Performance Measurement in State Science and Technology Programs." Policy Studies Journal 25 (3): 425-35. doi: 10.1111/j.1541-0072.1997.tb00032.x.

David, P. A., B. H. Hall, and A. A. Toole. 2000. "Is Public R\&D a Complement or Substitute for Private R\&D? A Review of the Econometric Evidence." Research Policy 29 (4-5): 497-529. doi: 10.1016/s0048-7333(99)00087-6.

Diamond, A. M. 1999. "Does Federal Funding 'Crowd In' Private Funding of Science?" Contemporary Economic Policy 17 (4): 423-31. doi: 10.1111/j.1465-7287 .1999.tb00694.x.

Eisinger, P. K. 1988. The Rise of the Entrepreneurial State: State and Local Economic Development Policy in the United States. Madison: University of Wisconsin Press.

Feldman, M., L. Lanahan, and I. Lendel. 2014. "Experiments in the Laboratories of Democracy: State Scientific Capacity Building." Economic Development Quarterly 28 (2): 107-31.

Feller, I. 1990. "Universities as Engines of R\&D-Based Economic Growth: They Think They Can.” Research Policy 19 (4): 335-48.

—. 1997. "Federal and State Government Roles in Science and Technology." Economic Development Quarterly 11 (4): 283-95.

- 2007. "Mapping the Frontiers of Evaluation of Public-Sector RD Programs." Science and Public Policy 34 (10): 681-90. doi: 10.3152/030234207x258996.

Fosler, R. S. 1988. The New Economic Role of American States: Strategies in a Competitive World Economy. New York: Oxford University Press.

Friedman, R. S., and R. C. Friedman. 1982. The Role of University Organized Research Units in Academic Science. State College: The Pennsylvania State University, Center for the Study of Higher Education, Center for the Study of Science Policy, Institute for Policy Research and Evaluation.

Hauger, J. S. 2004. "From Best Science Toward Economic Development: The Evolution of NSF's Experimental Program to Stimulate Competitive Research (EPSCoR). Economic Development Quarterly 18 (2): 97-112.

Hearn, J., A. Lacy, and J. Warshaw. 2014. "State Research and Development Tax Credits: The Historical Emergence of a Distinctive Economic Policy Instrument." Economic Development Quarterly 28 (2): 166-81.

Hecker, D. E. 2005. "Occupational Employment Projections to 2014." Monthly Labor Review (November):70-101.

Karch, A. 2007. "Emerging Issues and Future Directions in State Policy Diffusion Research." State Politics \& Policy Quarterly 7 (1): 54-80. doi: 10.1177/153244 000700700104.

Mallon, W. T., and S. A. Bunton. 2005. "Research Centers and Institutes in US Medical Schools: A Descriptive Analysis." Academic Medicine 80 (11): 1005-11.

Mintrom, M., and S. Vergari. 1998. "Policy Networks and Innovation Diffusion: The Case of State Education Reforms." Journal of Politics 60:126-48.

National Science Board. 2012. Science and Engineering Indicators 2010. Arlington, VA: National Science Foundation.

Payne, A. A. 2001. "Measuring the Effect of Federal Research Funding on Private Donations at Research Universities: Is Federal Research Funding More than a Substitute for Private Donations?" International Tax and Public Finance 8 (5): 731-51. doi: 10.1023/a:1012843227003. 
Plosila, W. H. 2004. "State Science- and Technology-Based Economic Development Policy: History, Trends and Developments, and Future Directions." Economic Development Quarterly 18 (2): 113-26. doi: 10.1177/0891242404263621.

Ruegg, R. T., and I. Feller. 2003. A Toolkit for Evaluating Public R \& D Investment: Models, Methods, and Findings from ATP's First Decade. Gaithersburg, MD: US Dept. of Commerce, Technology Administration, National Institute of Standards and Technology.

Santoro, M. D., and S. Gopalakrishnan. 2001. "Relationship Dynamics between University Research Centers and Industrial Firms: Their Impact on Technology Transfer Activities.” Journal of Technology Transfer 26 (1): 163-71. doi: 10.1023/ a:1007804816426.

Sapolsky, H. M. 1968. "Science, Voters, and the Fluoridation Controversy." Science 162 (3852): 427-33.

1971. "Science Policy in American State Government." Minerva 9 (3): 322-48.

Shadish, W. R., D. T. Campbell, and T. D. Cook. 2002. Experimental and QuasiExperimental Designs for Generalized Causal Inference. Boston: Houghton Mifflin.

Simon, H. A. 1978. "Rationality as Process and as Product of Thought." American Economic Review 68 (2): 1-16.

Taylor, C. D. 2012. "Governors as Economic Problem Solvers: A Research Commentary." Economic Development Quarterly 26 (3): 267-76.

Teich, A. 2009. AAAS Analysis of Federal Budget Proposals for R\&D in FY 2010. Washington, DC: American Association for the Advancement of Science: Forum on Science and Technology Policy.

True, J., and M. Mintrom. 2001. "Transnational Networks and Policy Diffusion: The Case of Gender Mainstreaming." International Studies Quarterly 45 (1): 27-57.

Vogel, R. C., and R. P. Trost. 1979. "The Response of State Government Receipts to Economic Fluctuations and the Allocation of Counter-Cyclical Revenue Sharing Grants." Review of Economics and Statistics 61 (3): 389-400.

Volden, C. 2006. "States as Policy Laboratories: Emulating Success in the Children's Health Insurance Program." American Journal of Political Science 50 (2): 294-312.

Wayne, L. 1982. "Designing a New Economics for the 'Atari Democrats'." New York Times, September 26.

Wilson, D. J. 2009. "Beggar Thy Neighbor? The In-State, Out-of-State, and Aggregate Effects of R\&D Tax Credits." Review of Economics and Statistics 91 (2): 431-36. doi: 10.1162/rest.91.2.431.

Youtie, J., B. Bozeman, and P. Shapiro. 1999. "Using an Evaluability Assessment to Select Methods for Evaluating State Technology Development Programs: The Case of the Georgia Research Alliance." Evaluation and Program Planning 22(1): 55-64.

Youtie, J., D. Libaers, and B. Bozeman. 2006. "Institutionalization of University Research Centers: The Case of the National Cooperative Program in Infertility Research." Technovation 26 (9): 1055-63.

Zucker, L. G., and M. R. Darby. 1996. "Star Scientists and Institutional Transformation: Patterns of Invention and Innovation in the Formation of the Biotechnology Industry." Proceedings of the National Academy of Sciences 93 (23): 12709-16. 